\title{
How to Implement an Accurate and Effective Costing System in Manufacturing Organizations ${ }^{\#}$
}

\author{
Boris POPESKO*
}

\section{Introduction}

The difficulty inherent in choosing a proper and accurate product costing method for manufacturing enterprises has been widely discussed by academics and practitioners. Elementary forms of traditional methods, which mostly featured absorption characteristics (absorption costing) and would have been used for calculating costs of products in manufacturing industries, have been described in detail by many authors. In the early 1980s, the limitations of these traditional absorption-costing systems became widely publicized. Several methods, such as variable costing and activity-based costing have since been created that avoid the inaccuracies of conventional costing methods. The variable costing method helps users avoid issues relating to imprecise overhead cost allocation, whilst calculating the capacity of the company by separately measuring the company's fixed costs. However, this method is unable to manage company's overheads effectively and is insufficient when it comes to producing information on total product cost.

Another method which potentially does away with inaccurate overhead cost allocation is activity-based costing (ABC). This avoids the basic drawbacks of traditional absorption costing systems by seeking out the true causes of overhead cost consumption. The activity-based costing method offers a very effective tool for defining the real causes of overhead cost consumption, by analyzing a company's processes and

\footnotetext{
\# The article is processed as an output of a research project The Methodology of Activity-Based Costing system implementation and its influence on the efficiency of manufacturing industries as registered by the Czech Science Foundation under registration number GA402/07/P296.

Boris Popesko, Ph.D. - assistant professor; Faculty of Management and Economics, Tomas Bata University in Zlin, Mostní 5139, 76001 Zlín, Czech Republic; <popesko@fame.utb.cz>.
} 
individual overhead activities, as well as allowing for the allocation of overhead costs to operations that brought about these costs. Nevertheless, utilization of the $\mathrm{ABC}$ system is hampered by a higher demand for nonfinancial information that has to be registered by the company, whilst being trickier to use and implement. In some cases, it can also provide very similar results to absorption costing. The questions are whether the application of $\mathrm{ABC}$ always brings about positive results, and if using a traditional absorption system always means that incorrect information is created. How should an industrial company set up an effective costing system for providing accurate data? These matters are going to be addressed in this paper.

\section{Costing systems and cost allocation principles}

Overhead cost allocation has become, in the past few decades, one of the most serious problems within cost management for companies. Accurately allocating overhead costs is one of the key criteria for effective product costing, meaning that correct managerial decisions can thus be made, an example being pricing decisions governing products.

Three elementary types of costing methods, which are different in the way they allocate overhead costs to products, are generally used. These are the conventional absorption costing method, variable costing method and Activity-Based Costing method. All of these have been thoroughly described by many authors (Drury, 2001; Král, 2006).

Traditional costing techniques were used for the purposes of overhead cost allocation during the 20th century. These are based on simplified procedures using principles of averages. In recent decades, such conventional concepts have become obsolete due to two major phenomena. The first of these is ever increasing competition in the marketplace, the necessity to reduce costs and the effect of having more detailed information on company costs. Secondly, there has been a change in the cost structure of companies. In terms of the majority of overhead costs, traditional allocation concepts, based as they are on overhead absorption rates, can often provide incorrect information on product costs.

The effect that plays a role in determining an inaccurate overhead cost allocation, in the case of absorption costing use, could be than described as 'averagisation'. In other words, the end results of allocating a 
proportionally average volume of costs of any type to all cost objects. For example, the cost for transporting an item to customer $\mathrm{A}$ is the true value of $50 €$, and transport to customer B is $900 €$. If we use traditional absorption costing, the transport costs will become part of the sales or distribution overhead, meaning all the costs of this type will be mixed together and then allocated through the absorption rate to the cost object, in proportion to the specific type of direct cost. All cost objects then will be subject to the principal average volume of transport costs. In the example this means $130 €$ for customer $\mathrm{A}$ and $110 €$ for customer $\mathrm{B} .{ }^{1}$

Fig. 1: The "Averagisation Effect" in the Costing Process

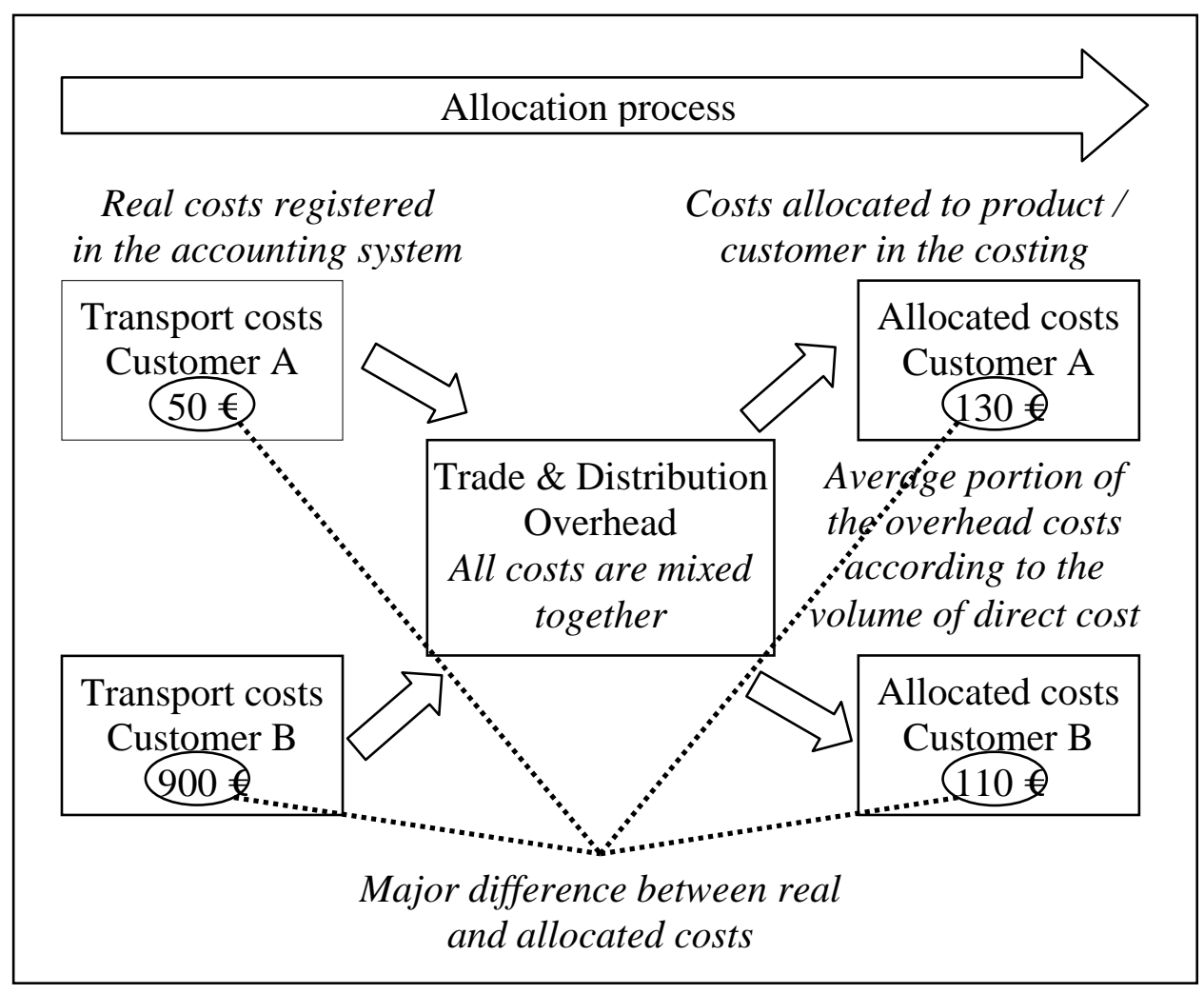

Source: own research

1 The difference is caused by the different level of direct costs of product A and B. If the direct costs are the same for both customers, and both customers order an identical product, the transport costs for both products will also be same - the average amount. This example shows the injustice of incorporating the relation of direct labour cost volume to trade or transport cost allocation. Direct labour and transport or trade costs usually bear no relation to each other. 
Glad and Becker (1996) defined a number of fundamental limitations in traditional costing systems:

- Labour, as a basis for assigning manufacturing overhead, is irrelevant as it is significantly less than an overhead and many overheads do not bear any relationship to labour costs of labour hours.

- The cost of technology is not assigned to products based on usage. Moreover, direct (labour) cost is replaced by an indirect (machine) $\operatorname{cost}(\mathrm{s})$.

- Service-related costs have increased considerably in the last few decades. Costing for these services was previously non-existent.

- Customer-related costs (finance, discounts, distribution, sales, after-sales service, etc.) are not related to the product's cost objects. Customer profitability has become as crucial as product profitability.

In some instances, especially when a company has a very homogenous output, few departments with overheads and customers very similar in nature, the absorption costing method should provide very accurate outputs, despite its limitations. (Staněk, 2003) The Absorption costing method boasts the one very important advantage - it is very simple to put into utilization. All the information the user has to gather together can be found in accounting books or product material and labour sheets.

Kim and Ballard (2002) defined the problems that can result from using traditional methods of overhead costing as:

- Cost distortion hinders profitability analysis.

- Little management attention to activities or processes of employees.

Case studies and analyses made by the author (Popesko - Novák, 2008) have shown one key feature of absorption-costing systems. When evaluating the production of wide-ranging products, the averagization effect causes costs of standard products sold in bulk to be overvalued. These are items that do not consume large portions of overhead activity costs. Another factor to be considered is the undervaluing of special limited-run products, which have great demands on a company's overhead activities. 
Looking back, the first method which tried to eliminate the shortfalls of absorption costing methods was the variable costing method. Time and again, this has been used to replace traditional absorption costing methods, in order to avoid an incorrect overhead cost allocation. The variable costing method is based on a separate allocation of variable and fixed costs, where fixed costs are not allocated to the cost objects at all. The method is very effective when short-term decisions are required. Some authors have stated that the variable costing method is a means to providing useful, extra information for decision-making (Drury, 2001). Generally, the most important limitations of the variable costing method are defined thus (Král, 2006):

- The construction of the method restricts managers to formulating short-term decisions which could clash with strategic objectives of the enterprises in question;

- Because fixed costs are not calculated, they are eliminated from consideration;

- Due to the fact that fixed costs are summarised, the causal relations between costs and objects are lost

The activity-based costing method is the tool which could bring about significant improvement in the quality of overhead cost allocation. The $\mathrm{ABC}$ process is able to incorporate both physical measures and causal principles in the costing system.

The basic idea of $\mathrm{ABC}$ is to allocate costs to operations through the various activities in place that can be measured by cost drivers. In other words, cost units are allocated to individual activities (e.g. planning, packing, quality control) in the first phase using a resource cost driver, with costs of those activities being allocated to specific products or cost objects, which in reality caused the incurrence of the overheads, using an activity cost driver in the second phase. (Fig.2) 
Fig. 2: Overhead Cost Allocation in ABC Systems

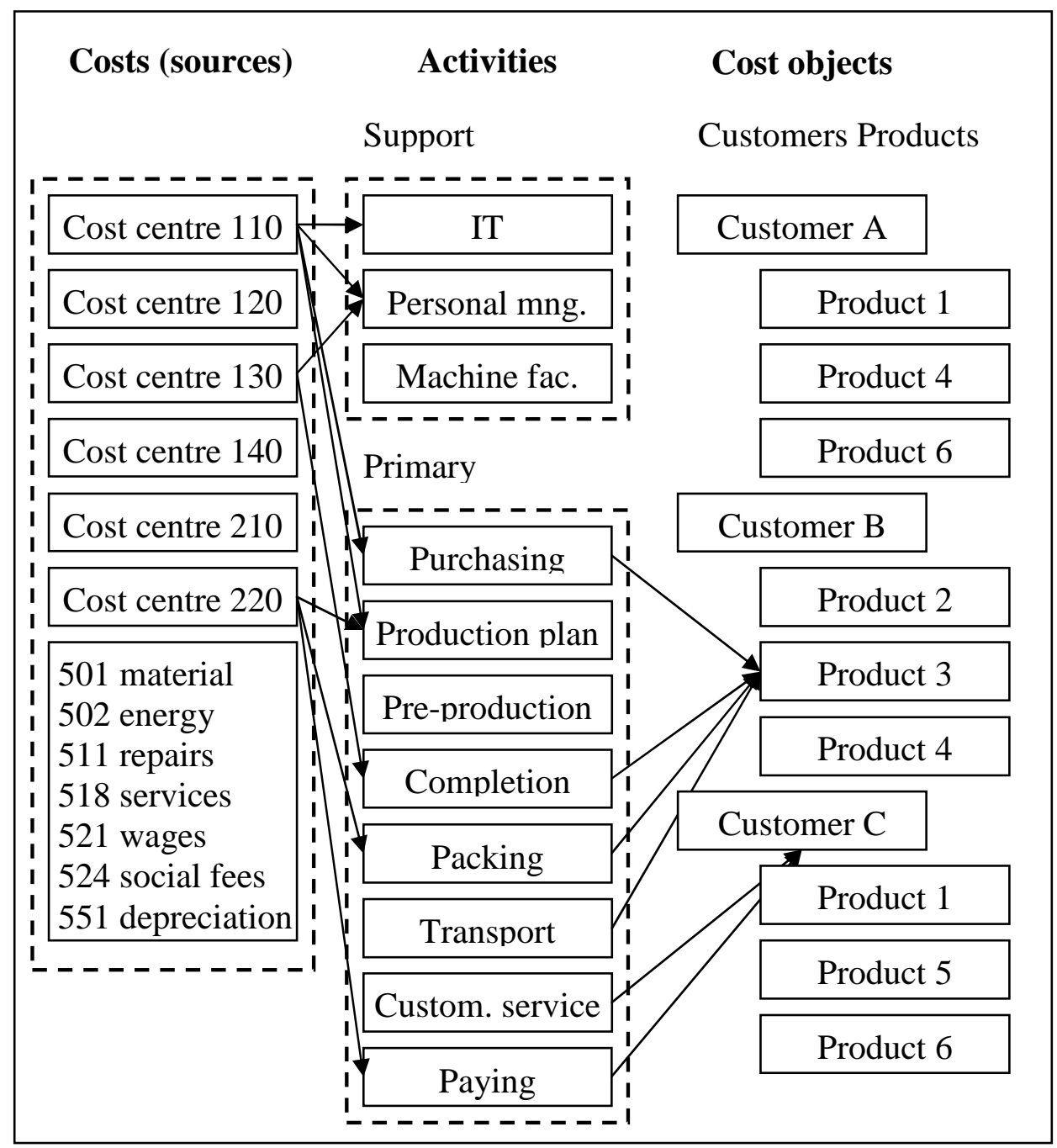

Source: own research

The advantages and benefits of $\mathrm{ABC}$ implementation have been widely publicized by many authors (Kaplan, Cooper, 1998; Staněk, 2003). Generally it generates, besides more accurate product costing, a wide range of complementary data for use when making managerial decisions. In contrast with traditional methods, $\mathrm{ABC}$ offers the following possibilities (Volkán, 2007): 
- The pertinence of costs calculated, because these are worked out following cause-effect criteria and factors between products and resources, finally informing strategic decisions at organizational level;

- The analysis of cost reduction possibilities or the rationalization of production processes;

- The calculation of indicators needed for total quality management;

- The identification of causes of poor results and performance, plus the pursuance of activities and processes.

Among the possibilities presented above, the ABC method creates advantages for competition for those who apply it. These are (Petrík, 2007):

- Identifying and analyzing the profitability of each customer - by calculating revenue per client and by establishing proper placement on the market of the company's products and services. Revenue per client is calculated whilst taking into consideration the costs of products and the prices they are sold at;

- Determining employees' liability - helping them to understand costs, to identify and analyze dead-end activities and to bring improvements to the system;

- Reducing economical risks - by adapting products and services to the marketplace with competitive prices.

Despite this, applying the $\mathrm{ABC}$ system has a number of limitations and drawbacks. The first of these is the necessity for much greater demand as regards input data, which could be difficult to obtain in some situations. The fundamental types of input data as defined by $\mathrm{ABC}$ methodology are (Cokins, 2001):

- Consideration of the organizational structure of a company, descriptions of activities performed, analysis of process maps and flowcharts, and specific details provided by interviews with employees.

- Information needed for setting resource cost drivers. For example, in order to assign costs for phone calls, it is necessary to analyze the activities for which the calls are made and in which portions.

- An additional analysis is required to put in place accurate activity cost drivers. This step means quantifying the number of cost 
drivers consumed in a period, plus defining output measures specific to each activity.

- Information needed for assigning activities to products - the consumption of activity costs by defined cost objects.

For any organization, the possibility exists that implementing $\mathrm{ABC}$ could prove ineffective due to these demands, especially if such an organization is not able to determine the efficacy and benefits of applying ABC. Therefore, which costing method provides an accurate means of product costing for manufacturing enterprises? It is known that absorption costing often produces inaccuracies in product cost quantification, whilst variable costing does not provide information about the total costs of products, and $\mathrm{ABC}$ is rather complicated to implement and operate.

\section{The cost structure of manufacturing enterprises}

Choosing the most precise and effective costing system for a manufacturing enterprise depends on the structure of company costs and operations. As mentioned above, absorption costing could provide precise data when producing products very much alike with a similar level of consumption of overhead activities.

Another issue of importance is that different groups of company costs (cost pools) bear a differing relation to cost objects, such as products or customers, and behave dissimilarly when changes occur in production volume. The logical conclusion in such a situation is to choose another principle of allocation for different cost pools.

Any author would classify company costs or overhead costs to categories according to factors potentially affecting cost behavior, their relations to cost objects, or simply according to the level of their variability. It is possible for such factors to be grouped into several levels of variability. Unit level costs vary in proportion to changes in units produced; batch level costs vary in proportion to the number of times it is necessary to prepare for a process; product level costs alter when a change is effected in the product or model; process level costs fluctuate when a process is replaced, and plant-wide level costs are incurred to sustain facilities and premises, e.g. security precautions. (Glad, Becker, 1996) In most traditional costing systems, non-volume related costs are even allotted at unit level. Kaplan and Cooper (1998) explicitly condemn this misleading practice. For that approach, a firm is envisaged as a 
hierarchy of costs, with each level representing a different type of cost variability (Fig. 3). The lowest three levels in the hierarchy are concerned with product related costs.

Fig. 3: Overhead Cost Allocation in ABC Systems

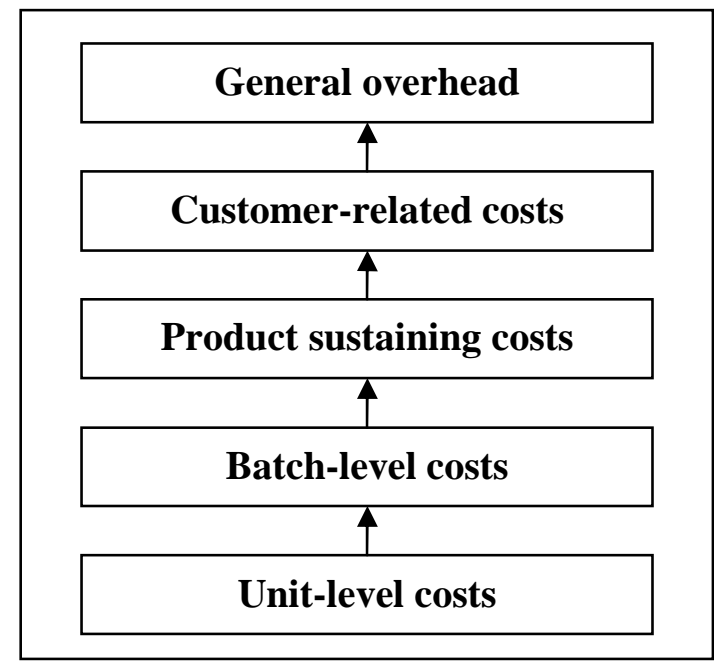

Source: own research

\section{Allocation principles governing modern costing systems (Findings)}

As mentioned above, one of the most serious problems connected with the practice of product costing is the allocation of non-volume related costs right down to unit level. An effective and accurate costing system, in that way, has to work with multiple cost objects. Distinct products and services usually comprise the most frequently used cost objects. In reality, it is possible to discern a much wider spectrum of cost objects. Using multiple cost objects, costing systems become much more complicated, but this principle is an important requirement for costing system accuracy. How can one allocate the costs of a sales department down to product level when the inputs consumed by each customer served by the department may vary widely, even if only one type of product is produced?

Based on the principles mentioned above, three major guidelines for accurate overhead cost allocation can be stated: 
1. Separate the company's overhead costs into cost pools according to the level of their variability.

2. Set multiple cost objects according to an analysis of cost pools.

3. Use an accurate cost driver for individual cost pools.

After carrying out several $\mathrm{ABC}$ implementations in recent years, several findings have been made which help define the best way of setting accurate methods for overhead cost allocation for individual cost pools. Of these, three full implementations made in manufacturing industries reveal the characteristics of the entire $\mathrm{ABC}$ system, with a feature of 30 to 40 activities (Popesko - Novák, 2008). Despite the fact that applying it brought about many benefits, including some regarding activity cost measurement and activity analysis, the final impact on changes to the way overhead costs are allocated does not correspond to the complexity of implementing it. This means that only small proportion of company costs were actually allocated to a product, using a manner different to that of absorption costing methods of the past. The same results - more accurate product costs - might be reached with an even simpler system.

Some authors (e.g. Lucas, 1997) point out the necessity to calculate product costs for decision-making purposes. Once costs are divided into separated cost pools using the Kaplan method, discerning them at unit level could be very simple. For such an allocation, it is possible to use the quantification of 'lower' cost objects. Despite their being a full allocation, differing results will be given, unlike those found by a traditional absorption costing approach.

It is worthwhile going through the individual cost pools to determine the optimum ways of allocating overhead costs and delineating them at unit level.

Unit related costs usually consume the largest portion of overhead costs. This type of cost consist of amounts which are unit related, e.g. working fluid consumption, and costs which are in fact fixed but closely related to the unit as a cost object. Two examples of such a cost could be machine depreciation or tool consumption of equipment. These costs are related to working hours and could be allocated using the machine hours cost driver. However, this cost group does not vary in relation to changes in operation hours. In fact, they should not be considered as unit related costs, because absolute unit related costs should bear features of direct, variable costs. Ideally, cost allocation within this cost group is best 
carried out using machine hours as a cost driver, with capacity utilization being driven through variable costing. This means that costs relating to unused capacity are not assigned to a machine hour rate but are quantified as loss caused by unutilized capacity. This step helps to 'variabilize' this category of costs and make them purely unit related.

Batch related costs represent the first group of costs not considered to be variable in relation to the number of units produced. Allocating these costs requires the splitting of batch and unit costs. Firstly, the costs per batch of any type of product have to be calculated. Here multiple cost drivers can be utilized for various activities, or a simpler method for estimation of the same. Potentially, such costs can be allocated by dividing all of the related costs of any batch by the number of units in the batch.

Product sustaining costs are those incurred when producing any type of product. The splitting of data regarding unit costs and others relating to the type of product is necessary for costs to be allocated precisely. The total product costs per product type may be calculated through activities and multiple cost drivers, or a simpler absorption method could be used. A problem could appear in the quantification or estimation of the total number of units of any product type produced. This cost object might very often resemble a customer cost object, if the product has been especially created for a client. In such situations, the number of units can be estimated as being the number of units in a customer's order.

Customer related costs are again those which need to be registered separately in relation to a customer's cost object. The quantification of costs of individual customers is calculated through the activities of one general activity with several levels of intensity. Following that step, it is necessary for proper overhead to pinpoint customer related costs at unit level by dividing them by the number of products, batches and units ordered by the customer. That means identical products should absorb different customer costs at that level.

General overhead means gathered groups of costs mostly with strictly fixed characteristics, which usually bear no relation to a company's outputs. These costs might be allocated in an identical manner as if worked out by absorption costing or could be calculated as fixed costs. In some cases, it is possible to allocate these costs through secondary activity rates measuring consumption of such support costs by primary activities. The 
Popesko, B.: How to Implement an Accurate and Effective Costing System in Manufacturing Organizations.

method chosen depends on the proportional volume of costs and their structure.

Fig. 4: Model of a Costing System using ABC Principles with Unit Level Cost Calculation

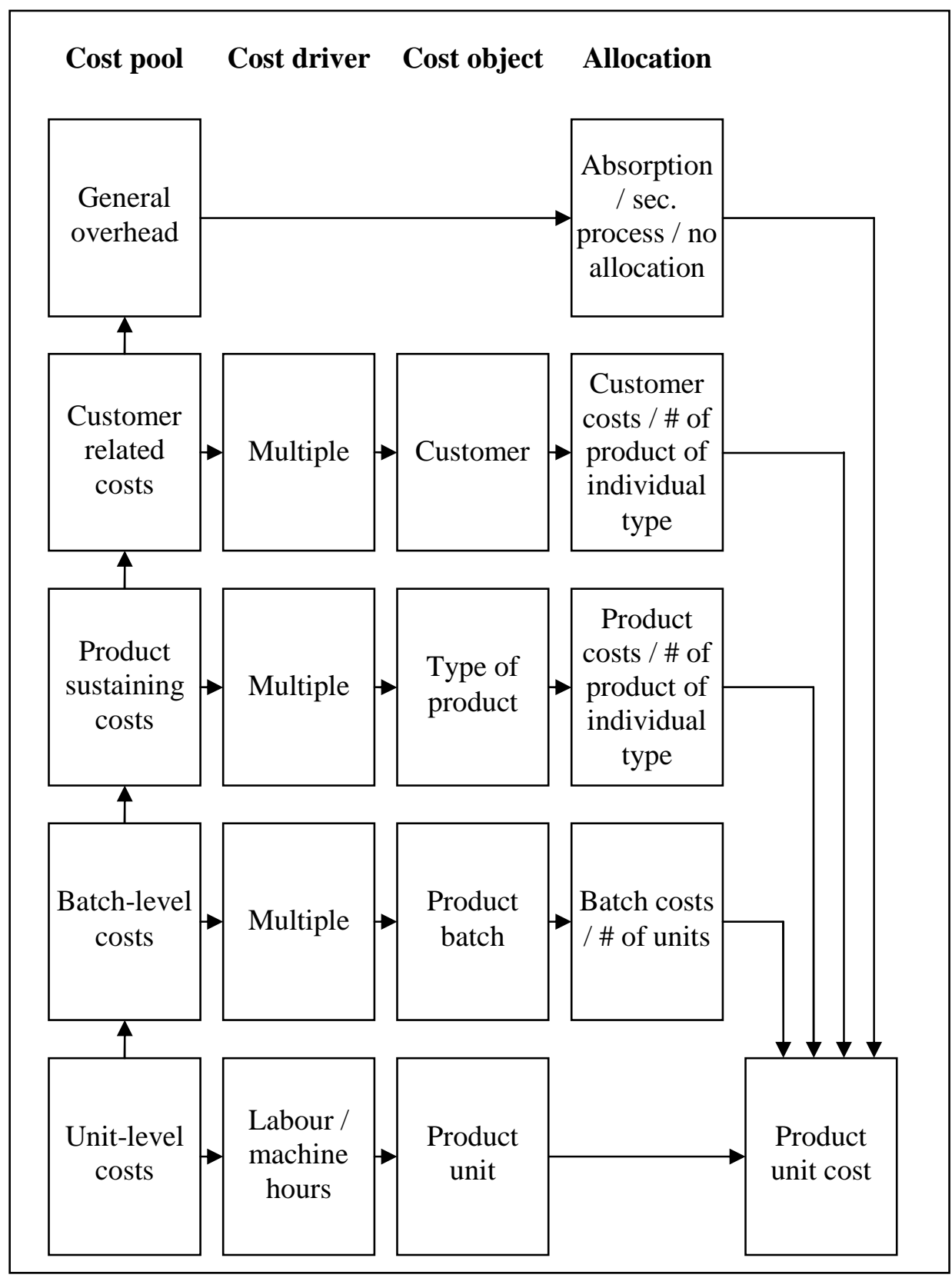

Source: own research 
This method of overhead cost allocation might prove very effective and reasonably accurate. As long as a company is able to quantify the costs of cost objects within individual cost pools and allocate them even in arbitrary way to the unit of production; (e.g. distinguishing between regular, new and exacting customers and using a classification for overhead cost allocation), allocation at unit level could prove very simple.

\section{Conclusion}

The activity-based costing method is, despite its advantages, often criticized for being unwieldy and complex, complicating its utilization. Any potential effects from applying $\mathrm{ABC}$ in manufacturing industries is also limited by the relatively large proportion of prime costs. In addition, a large portion of overheads could be driven through a simple machine hour cost driver. Accepting essential rules governing overhead cost allocation, as described in this paper, could improve the quality of a firm's costing system and reap benefits for the decision-making process. The main presumption for effectiveness of a costing system is to apply fundamental regulations outlined by $\mathrm{ABC}$ and maintain the complexity and structure of the costing system within feasible boundaries.

\section{References}

[1] Cokins, G. (2001): Activity-Based Cost Management: An Executive's Guide. New York, Wiley, 2001.

[2] Drury, C. (2001): Management and Cost Accounting. London, Thomson Learning, 2001.

[3] Glad, E. - Becker, H. (1996): Activity-Based Costing and Management. New York, Wiley, 1996.

[4] Kaplan, R. - Cooper, R. (1998): Cost \& Effect - Using Integrated Cost Systems to Drive Profitability and Performance. Boston, Harvard Business School, 1998.

[5] Kim, Y. - Ballard, G. (2002): Case study - Overhead cost analysis. [on-line], Gramado, Proceedings International Group for Lean Construction, c2002, [cit. 20 ${ }^{\text {th }}$ June, 2009], $<$ http://www.iglc.net/conferences/2002/Papers/PERFORMANCEME ASUREMENT/Kim\%20Ballard_Case\%20Study\%20-\%20Overhead $\% 20$ Costs\%20Analysis.pdf $>$. 
Popesko, B.: How to Implement an Accurate and Effective Costing System in Manufacturing Organizations.

[6] Král, B. (2006): Manažerské účetnictví. Praha, Management Press, 2006.

[7] Lucas, M. (1997): Absorption Costing for Decision Making. Management Accounting, 1997, vol. 75, no. 10, p. 42-44.

[8] Petř́k, T., Procesní a hodnotové řízení Firem a organizací komplexní manažerská metoda ABC/ABM (Activity-based casting, Activity-based management), Praha, Linde, 2007

[9] Popesko, B. - Novák, P. (2008): Activity-based Costing Applications in the Czech Republic. Lex et Scientia International Journal, 2008, vol. 15, no. 1, pp. 69-76.

[10] Staněk, V. (2003): Zvyšování efektivnosti procesním ř́zením nákladů. Prague, Grada, 2003.

[11] Volkán, I. (2007): $A B C \& A B M$ - The Couple which Prevails Cost Calculation and Modern Administration for Performance. Journal of the Accounting and Management Information Systems, 2007, vol. 15 , no. 19 , pp. 284-292. 


\title{
How to Implement an Accurate and Effective Costing System in Manufacturing Organizations
}

\author{
Boris POPESKO
}

\begin{abstract}
The objective of the article is to define rules for establishing a high quality costing system to measure the costs of products, customers, and other cost objects in a manufacturing enterprise. The pros and cons of all existing costing methods are discussed in the article, as are the methods themselves. Furthermore, their allocation principles are investigated, along with the nature of costs and the behavior of cost elements in major enterprises. One expectation is that different principles of cost allocation will have to be applied to different types of costs, based on their relation to the output of a company's processes.

Initially, several analyses are performed in order to identify the methods that prove insufficient for effective and accurate cost allocation. These methods, despite their inaccuracies, are very frequently used in practice. Also, cost elements or cost pools inside an organization, which tend to be hard to allocate accurately, are identified. Secondly, several implementation projects on the activity-based costing system, have been analyzed in order to consider the effectiveness of utilizing such a system in a manufacturing enterprise. Furthermore, the general rules for allocating cost pools or activity costs are outlined. Thirdly, different principles for cost allocation are defined for individual cost elements.

The result of the article is to define the rules for implementing a costing system which provides accurate and correct information. These rules should provide for a compromise between the use of a traditional absorption costing system and the activity-based costing system, by pointing out the most important allocation principles.
\end{abstract}

Key words: Costing Methods; Cost Allocation; Activity-based Costing.

JEL classification: M1; M41. 